\title{
PRINCIPLED ATHEISM IN THE BUDDHIST SCHOLASTIC TRADITION
}

\section{INTRODUCTION}

In their systematic presentations of religious philosophy, the Indian Buddhists consistently defended the position that belief in an eternal creator god who superintends his creation and looks after the concerns of his creatures is a distraction from the central task of the religious life. This was clearly the position taken in the early Pāli literature and in the Theraväda philosophy based on that literature, but even in the later Mahāyāna writings such as the Lotus Sütra and the Lañkāvatāra Sūtra, in which buddhahood is portrayed not as a feature of the isolated career of Siddhārtha Gautama but rather as a constant feature of the entire cosmos at all times, great care is taken to try to distinguish the concept of the cosmic Buddha-nature in the forms of Dharmakāya or Tathāgatagarbha from the concept of a creator god. The Buddhists were, for whatever reasons, eager to avoid falling into a theistic position. The motivation behind the present paper has been to discover what those reasons were.

Section 1 will outline how the issue of God's existence is treated in the early Buddhist literature, especially in the Suttapitaka, where systematic Buddhist philosophy begins. Section 2 will review the treatment of the question of divine creation as an issue in the systematic philosophy of such thinkers as Vasubandhu (400-480), Dharmakïrti (600-660), Sāntarakṣita (725-788) and Kamalaśila (740-795). And section 3 will show how the arguments for atheism are isomorphic with the arguments for a variety of other positions to which the Buddhist philosophers were committed.

\subsection{BUDDHIST ĀGAMAS ON THE QUESTION OF GOD}

In the Nikāya literature, the question of the existence of God is treated primarily from either an epistemological point of view or a 
moral point of view. As a problem of epistemology, the question of God's existence amounts to a discussion of whether or not a religious seeker can be certain that there is a greatest good and that therefore his efforts to realize a greatest good will not be a pointless struggle towards an unrealistic goal. And as a problem in morality, the question amounts to a discussion of whether man himself is ultimately responsible for all the displeasure that he feels or whether there exists a superior being who inflicts displeasure upon man whether he deserves it or not.

An instance of the epistemological treatment of the question of the highest good occurs in the Tevijja Sutta, the thirteenth sutta of the Digha Nikāya. In this sutta there is an account of a dispute between two young brahmins, Vāsetțha and Bhāradvāja, over the issue of which religious practices lead most directly to union with Brahmā. Brahmā is typically treated in the Nikāya literature as an object of brahmanical devotion who is believed by his devotees to be the master over whom no other being has mastery (abhibhū anabhibhūto), who sees everything (añnad-atthu-daso), the mighty one (vasavatti), who is lord, maker, designer, chief, creator, master and father of all beings that have been and of all beings that shall be (issaro kattā nimāttā setțo sañjitā vasī pitā bhūtabhavyānam). ${ }^{1}$ Moreover, companionship with Brahmā (Brahma-sahavyatā) is believed to be the state of salvation, and so whatever set of practices leads most directly to companionship with Brahmā may be considered the most direct path to salvation (añjasâyano niyyāniko). ${ }^{2}$ But the brahmin students Vāsețtha and Bhāradvāja have heard from their respective teachers differing accounts on which practices lead to the goal that they both desire. And so they decide to approach Gotama the Buddha to see whether he can decide which party is right in this very important dispute.

On being told the nature of the dispute between Văsetțha and Bhāradvāja, Gotama Buddha begins by asking the disputants a few questions of his own, and the answers to the questions show that the young brahmins believe that there are many alternative paths that lead to Brahmā, but the dispute is really over which path is most direct. On learning this much, Gotama Buddha then pursues the supposition that there are paths that lead men to meet Brahmā face to face. What, asks the Buddha, entitles us to believe that anyone meets Brahmā face to 
face? Prompted by Gotama's questions, the young brahmins concede that no living brahmin teacher claims ever to have seen Brahmā face to face, nor has any living brahmin teacher's teacher, nor has any teacher in the lineage of teachers for the past seven generations. Moreover, not even the Rsis, the ancient seers who made the Vedas available to man and whose words the brahmin priests learn and chant and transmit down through the generations, claim to have seen Brahman face to face. What we have then, is the astonishing state of affairs in which the followers of the brahmanical religious tradition are striving towards a goal for the existence of which no one has any evidence. Their religious goal, says the Buddha, is laughable (hassaka), vain (rittaka) and empty (tucchaka). ${ }^{3}$

It is not only fellowship with God that is dismissed in this way. Very nearly the same treatment is given to a Jaina disciple and his teacher in the Cüla-Sakuladāyi-sutta and the Vekhanassa-sutta respectively, suttas seventy-nine and eighty in the Majjhima Nikāya. Here the Jainas are depicted as seeking after a "highest lustre," a lustre superior to which and more excellent than which there is nothing. On hearing of this unsurpassed lustre, the Buddha's response is exactly the same as his reaction to the idea of comradeship with the mighty lord and creator of all beings: he challenges the devotees to point to that to which they are devoted. When they cannot do so, Gotama spins out an analogy to illustrate to the devotees the nature of their search. They are, he says, like a young man who goes about saying "I love and cherish the loveliest woman in the land," but who cannot say whether she is of high birth or low, of pale complexion or dark, a city-dweller or a villager, and does not even know what her name is. In short, the poor fool does not know, directly or indirectly, the identity of the woman with whom he claims to be in love. We are entitled to wonder, then, whether he is really in love at all.

The Buddha's reaction to those who seek to meet the creator or who seek the unsurpassed lustre is not to deny that such things exist. Rather, it is to take the epistemologically cautious stand that even though the loveliest woman in the world may exist, one might very well see the person who uniquely answers to the description of the world's loveliest woman and yet not realize that she is the person who answers to that description. Furthermore, it is not clear how one could 
ever be certain that a given woman were the loveliest in the world, unless he could see every woman in the world and know that he had seen every woman. Similarly, it is not clear how a religious seeker could be sure that he had correctly identified the greatest lustre or the master over whom no other being has mastery. And, as we see in the Brahmajāla Sutta in the Digha Nikāya, the case can be made that people often misinterpret religious experiences and draw false conclusions from them, which should make one suspicious of even the very claims of direct experience of such things as unsurpassed masters. Until his identification of the supreme being is specific and certain, the religious seeker may be said to be pursuing such an ill-defined and nebulous goal that it becomes difficult to determine whether a given set of practices leads toward or away from the desired goal. In contrast, the goal of nirvāna towards which Gotama's disciples strive is sufficiently definite - the elimination of selfish desire and hostility that a disciple can have a very clear idea of whether he has or has not reached it and whether he is or is not making progress toward it. It is a goal to be realized in this life, not in some future existence, says Gotama, and he makes no promises to anyone other than that nirvāna can be achieved by anyone who strives diligently to attain it. The definiteness of the goal of Buddhist striving is what makes that goal more worthy of pursuit than the goals of the Brāhmanas and the Jainas - this seems to be the message so tirelessly repeated in the Nikāyas. And so the Buddha Gotama is portrayed not as an atheist who claims to be able to prove God's nonexistence, but rather as a skeptic with respect to other teachers' claims to be able to lead their disciples to the highest good.

The above described reactions of the Buddha to the claims of other religious teachers are simply instances of his well-known aversion to speculative views concerning matters that are beyond man's ken. Speculation about such matters as whether the universe is beginningless or had a definite point at which it came into being was regarded as a distraction from pursuits closer at hand, and time spent thinking about such things was regarded as wasted time that could more profitably be spent on gradually ridding oneself of those counterproductive attitudes and beliefs that, when acted upon, bring further distress rather than the desired relief from the inconveniences of the 
human condition. That the attitude of the Buddha as portrayed in the Nikāyas is more anti-speculative than specifically atheistic is illustrated by a refrain that is frequently repeated in the Brahmajäla Sutta. Here Gotama the Buddha differentiates himself from other teachers on the grounds that he, unlike them, does not propound doctrines concerning the nature of the self after death. Furthermore, unlike other teachers, the Buddha realizes that "these dogmatic tenets thus taken up and thus embraced will lead to such and such consequences and will lead to such and such a destiny." 4 What the reader of this sutta is left to conclude is that if the consequences of embracing certain tenets about the existence of the self were healthy, then Gotama would certainly recommend that his followers embrace them; but, since he in fact repeatedly warns people to avoid embracing certain tenets, there must be something about them that he regards as unhealthy or counterproductive.

Some insight into why it is that Gotama regarded the belief in God as unhealthy, as an obstacle to spiritual progress, can be gained by looking at the Devadaha-sutta, the one hundred first discourse in the Majjhima Nikāya. ${ }^{5}$ Here we find an enumeration of the types of reasons that people often give for why they experience pleasure and pain. Among the five reasons, one is that pleasure and pain are created by God (issara). This view is not refuted in the sutta in question, which is a polemical dialogue against the Jainas. All that is said is that if God creates pleasure and pain, then the Jainas are made by an evil creator who inflicts much suffering on them through their programme of austerities; the Buddha, on the other hand, feels only pleasant feelings in his dispassionate state, and so, if pleasure be created by God, then the Buddha's creator must be a kind one. The other theories, incidentally, as to why men experience pleasure and pain are that such experiences are (1) the result of actions done in the past, (2) the result of fate, (3) innate to certain species of beings, and (4) the outcome of efforts undertaken in the present life. A Buddhist monk, says this sutta, realizes that the source of all displeasure is selfcentred craving (tanhā), while the source of pleasure is nonattachment and dispassion. And so, while the reader is left to conclude that it is attachment rather than God, actions in past lives, fate, type of birth or efforts in this life that is responsible for our experiences of sorrow, no 
systematic argument is given in an attempt to disprove the existence of God.

Nor do we encounter actual arguments against the existence of a creator god in later Theravāda works such as Buddhaghosa's Visuddhimagga. Here it is explained that the Buddha's teaching that craving is the root cause of all distress is offered as a corrective to such false theories as that the world with all its woes is the creation of a god (issara), or that it is an evolution of primordial matter (padhāna) as in the Sāmkhya system of philosophy, or that it is a product of time or fate or that it is an accidental by-product of material elements. ${ }^{6}$ But how and why these theories are false is not explained.

\subsection{VASUBANDHU'S DISCUSSION OF DIVINE CREATION}

Like Buddhaghosa, the dogmatist Vasubandhu refers to alternative accounts of how the world and its attendant suffering began, and he too refers to the views that it began through divine creation, through an evolution of primordial matter, or on account of time, fate or pure chance. Unlike Buddhaghosa, however, Vasubandhu supplies arguments designed to show why these various theories are inadequate. Concerning the theory of divine creation of the world, Vasubandhu focuses his attention on three issues. First, he explores the question of how a single, undivided God, existing at all times, can create a complex universe the parts of which arise in temporal sequence. Second, he examines God's psychological motivation in creating the world. And third, he looks into the relationship between God as principal creator and auxiliary causal factors that go into making up the world. Vasubandhu treats these issues in about one page of Sanskrit prose. Later Buddhist philosophers wrote more extensively on each of these three issues than did Vasubandhu, but for the most part they did not explore other issues beyond these three. Let us look at the issues one by one, seeing first how Vasubandhu treated each one and then how later philosophers expanded on his treatment.

\subsection{GOD'S UNITY}

The position that Vasubandhu and most other Buddhist scholastics 
accepted is that the world is caused by a virtually infinite number of causes, namely, the intentional actions of the countless sentient beings who have lived through all beginningless time. The belief that there is a single entity responsible for the rich diversity of experiences is fundamentally wrong-headed. "The world," says Vasubandhu, "does not have a single cause. Although they generate their own actions in birth after birth, the poor wretches of unripened wisdom, who experience the consequences of their own actions, wrongly contrive a supreme God." "And so it should be noted at the outset that Vasubandhu's arguments are designed to demonstrate the untenability of any theory whereby the world's diversity is traced to a single source. In particular, Vasubandhu points out that all his arguments for the necessary plurality of causes does as much damage to the Sāmkhya theory of primordial matter (pradhāna, or prakṛti) as to the theory of divine creation. ${ }^{8}$

Given that understanding of Vasubandhu's own position, let us see how he criticized the positions that were contradictory to it. He begins by saying:

If the world had a single cause, whether that single cause be God or something else, the entire universe would have to arise all at once. But what we observe is that beings occur one after another. Now that fact could be a function of God's intending for each individual thing that it arise at a given time and disappear later. But in that case, since there are numerous intentions, it would turn out that the cause of the world is manifold. Moreover, that plurality of intentions would be simultaneous, for the reason that God, which is their source, putatively has no internal divisions. ${ }^{9}$

As will be discussed more fully below in section 3, this argument, or various modifications of it, was one to which Buddhist academics repeatedly resorted, not only in their arguments against theism but also in their arguments against any hypothetical entity that was supposed to retain its singularity while possessing a plurality of parts or characteristics. By the time of Vasubandhu a real thing (dravyasat vastu) is defined as any ultimate simple, that is, anything that cannot be reduced either physically or conceptually into smaller components. ${ }^{10}$ Consistent with that understanding of what it means for something to be a real thing, Vasubandhu argues that if it is claimed that God is real and therefore simple, then it cannot consistently be said that he also have a plurality of separate intentions, one for each 
object in the universe. But if God's uniformity is taken seriously, then he must have only one intention that is applicable to everything at once. And if that single intention is "Let it be," then everything must be at once. A simple God can create, it would seem, only a perfectly static universe. But the universe that we experience is not static.

Vasubandhu anticipates one objection to the above line of reasoning: "Now one might argue that even if God's intentions occur all at once, the [created] universe need not do so, since it is created in accordance with divine will." "11 God's mind could have exactly the same set of intentions at each moment in history, and in that case it could not be said that he undergoes change. His unchanging set of intentions could be: "Let $A$ be at $t_{a}, B$ at $t_{b}, C$ at $t_{c} \ldots X$ at $t_{x}$." Each event in history could then occur in the sequence that we observe and still the sequence could occur according to a constant set of volitions. Vasubandhu rejects this possibility, saying: "That is not so, because there is nothing that distinguishes those [intentions at one time] from [those that occur] later." 12 The point appears to be that if God's set of volitions is constantly in the form "Let all the events of history occur in a prescribed order," the problem still remains that in order for the intentions to be realized by being translated into action, some change must occur in something; some potentiality must be converted into an actuality. That change that must occur cannot occur in God himself, for he is changeless. It must, then, occur outside God. But if that which converts God's intentions into actions is something outside God, then we should say that it, rather than God, is the creator of the universe.

This question of how potentiality becomes actuality is taken up somewhat more fully in Dharmakirti's arguments adduced to demonstrate the nonexistence of God. The first observation that Dharmakirti makes is that a permanent, unchanging entity such as God would have to have exactly the same nature before the creation of the world as after; there would be no difference whatsoever between God as creator and God as a being that is not yet a creator. ${ }^{13}$ To be a cause of something is to undergo some change, as when a seed and the earth in which it is planted undergo changes in nature as they evolve into a shoot. ${ }^{14}$ But if God suffers no changes in nature, then he surely cannot be regarded as the cause of anything. ${ }^{15}$ Even if 
there is no apparent change in nature within the cause itself, there must be some change in at least the cause's circumstances. For example, it must move from one place to another, or it must come into contact with an object with which it was not previously in contact. A weapon, for example, can be recognized as the cause of a wound in the body only if the body is not wounded before contact with the weapon, then contacts the weapon, and immediately upon such contact develops a wound. But if God is supposed to be omnipresent and therefore always in contact with everything, it cannot then be the case that God comes into contact with a thing with which he was not previously in contact, and so it is impossible that a change in some object be due solely to that object's change in relationship with God. ${ }^{16}$

Central to Dharmakirti's argument is the claim that no action is possible without change, and so no unchanging thing can perform the action of creating the universe. In this connection he anticipates a possible counterexample that might be cited to disprove this central claim. A sense object such as a patch of colour apparently undergoes no change at all when it is perceived, and yet it is acknowledged as a cause of sight, as can be shown by pointing out that sight occurs when a patch of colour is present and fails to occur when no visible object is present. Is it not possible, therefore, that God can be an unchanging cause of the universe in the same way that a patch of colour is an unchanging cause of vision? ${ }^{17}$ Dharmakirti replies to this hypothetical counterargument by stating the principle that nothing can become an actuality without first being a potential. A visible object could never actually be seen unless it had the potential to be seen, and so a sense object must have an intrinsic potential to be sensed, and this potential must be in some way triggered into actuality. Similarly, if God is a creator of the universe, it must be admitted that he has a potential to create that exists prior to his actually creating anything. But if this is so, we must ask how that potential becomes realized. A visible object's potential to be seen, for example, is triggered into actuality by factors extrinsic to the visible object itself; there must be such factors as light, a sentient being with a functioning eye and an attentive mind and so forth, or else the potentially visible object cannot actually be seen. But is there a similar set of factors extrinsic to God that are required to trigger his potential to create? If so, then God is at least not a 
sufficient condition for creation of the universe - whether or not he is a necessary condition is a separate question, to which we shall return in section 2.3 below. But if there are no factors extrinsic to God that are required to trigger his potential to create, then the conversion of God's potentiality into actuality must be seen as an action that he himself performs. But if God performs an action, then he must undergo change and thus cannot be permanent.

Dharmakirti could also have pointed out in this context that serious problems result from saying that a thing has an intrinsic potential to act. For following the parallel to an argument made in another context, we can see that if we claim that a certain object has an intrinsic potential to act, then we are forced to conclude that the object realizes that potential in every moment of its existence. ${ }^{18}$ For otherwise we have no means of explaining why that which is a mere potential at one moment becomes an actuality in the next. Just as an object that has an intrinsic potential to perish must perish in every moment of its existence (and must, therefore, exist for only one moment), so also God, if he has a wholly intrinsic potential to create, must create in every moment of his existence. But this means that there is never a time when God exists and the created universe does not. If God is beginningless, then so is the universe. And if the universe is beginningless, there is no creation after all and therefore no need to answer the question of who brought the creation about.

Post-Dharmakīrtian Buddhist academics, such as Sāntarakṣita and Kamalaśila, provided a natural corollary to Vasubandhu and Dharmakirti 's conclusions that a changeless being cannot perform the action of creation. Not only can a changeless being not create the world of sequential events, says Sāntarakșita, but he cannot even know about the world of change. Even if there were a simple, beginningless and endless being endowed with the faculty of intelligence, such a being could not know the events of the transitory world, for if such a being knew each event separately as it occurred, then he would have a plurality of cognitive acts and would lose his unity. But if he knew all events at once, then he would not know the essential characteristic of events, which is that they occur in sequence. Knowing all events in history at once would be like hearing every note in a melody played at once rather than in sequence. Just as the essence of a melody lies in 
the sequentiality of the notes rather than in the mere presence of the notes, the essence of history lies in the sequentiality of events. And so, concluded Sāntarakșita, if God is indeed simple and eternally changeless, he cannot participate in or know about history, and so those of us who are caught in history can derive no benefit from God's existence at all.

As can be seen from the above discussions, Vasubandhu's claim that a complex world cannot have a simple and thus eternal cause was a very powerful and rich claim indeed, which thinkers were still exploring and expanding upon for several centuries.

\subsection{GOD'S MOTIVATIONS}

A second question that Vasubandhu raises about the theory of divine creation focuses on the issue of why a self-sufficient and supposedly perfect being would either need or wish to create anything at all. Vasubandhu asks:

For what purpose would God expend so much effort in creating the world? Perhaps for pleasure? Well, if God cannot make an effort without pleasure, then he has no control over that, and thus he has no control over anything else either! ${ }^{19}$

Even more alarming than the possibility that God's creation of the universe was a mere indulgence in hedonism is the possibility that it was an act of cruelty, as evidenced by God's apparent willingness to allow his creatures to err and to suffer for their errors:

And if God allows his creatures to be afflicted in hells by many guardians and takes pleasure in that, then we should prostrate ourselves before such a God as that! For the verse composed about him is very apt that goes:

\footnotetext{
Because he torments, because he is severe, because he is cruel and full of might, because he devours flesh, blood and marrow they call him the Dreadful (Rudra). ${ }^{20}$
}

In contrast to the argument concerning the impossibility of the creator's unity, which became the principal Buddhist argument against the existence of God, this issue of the creator's motivations was not stressed by Dharmakīti, Sāntarakșita or Kamalaśila. In his Nyāyamañjari, however, the Hindu theistic philosopher Jayanta Bhața 
devotes a section to arguments adduced by atheists before providing his own arguments in favour of God's existence. Among the arguments that Jayanta cites against God's existence is a version of Vasubandhu's question concerning motivations:

Did the Lord of creation undertake the creation of the universe just as it is after he had pondered upon a purpose? If the undertaking were purposeless, then he would be like a madman, in that his actions would not be preceded by reflection. ${ }^{21}$

But, Jayanta reports his atheist opponent as saying, God is putatively endowed with every possible joy and is free of passionate desire, and so it is difficult to see what he would think he had to gain by creating a universe without which he is already quite content. The standard answer that the theist gives to this question is that God created the world out of compassion. But, says Jayanta's adversary, for whom are we to believe that God has compassion? Compassion is a response to beings who are in pain. But surely there can have been no beings in pain before the creation of the universe; indeed, it was precisely because of the creation that previously contented souls began to feel pain and anguish. Moreover, since God is supposedly omnipotent, he might have created a universe in which sentient beings felt only joy and happiness instead of this sorry world in which what little pleasure there is is fleeting and serves only to taunt us in our misery. Perhaps we can conclude only that the creation was a joke (krị̄ā) that God played to amuse himself. But, Jayanta has the atheist say, if the creation was a joke, it is one the humour of which is too subtle for the sentient beings to appreciate: "Neither is the Magnanimous One's joke appropriate, which causes dread in all his creatures, nor is this great effort to play it." 22

As effective as this investigation into divine psychology might be in casting doubt upon the purity of the creator's motivation in making the world such as ours, this line of attack was not as commonly used by Buddhist academics as the more fundamentally persuasive arguments based on metaphysical considerations such as the problem of God's unity and permanence. There is no need, then, for us to dwell any longer upon the teleological issue. 


\subsection{GOD AS ONE CAUSAL FACTOR AMONG OTHERS}

We have already seen how Vasubandhu, who was followed in this by Dharmakirti, argued that God cannot be regarded as a sufficient condition of creation, that is, as a wholly self-sufficient creator with an innate self-actualizing potential to enact the creation of the world. But the possibility still remains open that God might be one of several necessary conditions in the origin of the universe. Historically, in fact, this view of creation, whereby God is a sentient, noncorporeal agent whose volition puts coeternal atoms into motion to make up macroscopic corporeal forms and puts eternal souls into these created physical bodies, is the one adopted by most Indian theists, who generally condemned the theory of creatio ex nihilō as absurd. In dealing with the possibility that God requires factors outside himself in order to create the universe, Vasubandhu first considers the possibility that the creator's dependence upon other things is due to his being himself an effect of other causes. If anyone were to hold such a view, then he would have to answer what it was that caused the creator's causes and so on ad infinitum. In fact, says Vasubandhu, this theory amounts to admitting that the universe is beginningless, which is the view accepted by Buddhists; but if one accepts that the universe is beginningless, there is of course no need to posit a creator at all. ${ }^{23}$

The possibility that God's dependence upon other things is in the nature of his being the effect of those other things is not to be taken very seriously, since no one actually advocates such a view, and Vasubandhu's refutation of it must be seen as a result of a good philosopher's penchant for thoroughness. Far more serious, however, is the claim that the world made up of insentient matter requires some conscious force to put it into motion. The principal argument of the theistic philosophers in India, in fact, was that since all complex products require sentient makers and since the universe is a complex product, the universe must have a sentient maker.

The above argument was one that the Buddhist academics tended not to reject; the medieval Indian Buddhists, in other words, did not advocate a position anything like the view accepted by most modern thinkers to the effect that the universe is for the most part uninhabited and that sentient life is a development that has come about relatively 
recently in the history of an inconceivably vast expanse of lifeless matter. On the contrary, Buddhist mythology and systematic philosophy generally endorsed the view that the vast universe is everywhere populated by sentient beings and that the shape the universe takes is an accommodation to the force of the constant fruition of the multitudes of deeds performed by those sentient beings throughout the history of a beginningless universe. The medieval Buddhist view, in other words, is no more attuned to modern scientific views than is the theistic view of creation that the Buddhist academics sought to refute. What in particular Vasubandhu rejected in the theistic theory that the universe is sustained and influenced by noncorporeal sentience was the alleged unity of that sentience. If the material universe obeys the dictates of only one sentient force, namely God, then human beings and other sentient beings must be ultimately powerless, and their role in making all the manufactured items of ordinary life must ultimately be denied. As Vasubandhu puts the matter:

He who accepts that there is but one cause of the universe must deny the obvious human effort in other matters. And he who fancies God as a creator along with [other] causal factors would merely be proclaiming his devotion, for we do not observe the operation of anything other than [the other] causal factors when something arises from them. ${ }^{24}$

Dharmakirti did not develop this argument in his discussion of the theory of divine creation, but Sanntarakșita expanded Vasubandhu's argument considerably. First, Sāntarakșita recapitulates the theist's claim as follows: "Others regard God as the cause of all things that are produced. No insentient being, they say, produces its effects by itself." 25 But, he argues later, granting that an insentient universe cannot put itself into motion does not force us to conclude that there is but one sentient being who motivates insentient nature. On the contrary, in everything that we observe in the world around us we see that a multiplicity of effects is preceded by a multiplicity of creators. It takes many ants to make an anthill, and many men to construct a city and all the things in it; potters make pots, weavers make cloth, carpenters build houses and so forth, but we never observe that behind all these many manufacturers of things there is but a single sentient being at work with a single will. ${ }^{26}$ If there were but a single purposive will driving all apparently independent sentient beings, there would be no 
conflicts among beings, but this is hardly what we in fact observe. And so, concludes Santarakșita, "We have no dispute with what is claimed in general, namely, that [products] are preceded by something intelligent, for diversity is born of deliberate action. In the argument for [products'] being preceded by a single, eternal intelligence, the conclusion is frivolous and [the evidence is] inconclusive, because it is observed that palaces and so forth are built by many people." 27

Closely related to the general issue of whether God is one factor among many in building and sustaining the universe is the contention held by some theists that God's function is an essentially administrative one in that he keeps an account of all the deeds of his creatures and dispenses retribution in accordance with merit. The crucial question to be asked in this connection, say the Buddhists, is whether or not God actually tampers in any way with anyone's stock of merit and demerit. If not, then it must be admitted that God is essentially doing nothing more than being aware of the natural process of the ripening of past deeds that would presumably take place whether or not he were conscious of it. God would then be much like us, a powerless bystander witnessing a series of virtually inevitable events. Positing such a god has no explanatory value, and paying respects to such an impotent figure would provide little comfort to the worshipper. And so, if God's administrative talents are to command our respect, it would appear to be more promising to assume that God can and does play a decisive role in the maturation of the seeds of past deeds into present realities. And to say that God plays a decisive role amounts to saying that he accomplishes something that the natural fruition process itself would not accomplish. But what can God accomplish that could not be accomplished by a natural process of individual karmic seeds maturing into new realities? The most likely answer to this question is that God must somehow be able to alter the karmic configurations of sentient beings, to give beings rewards and punishments that they do not rightly deserve on the basis of the moral momentum of their own actions. But if God has this power to give those beings under his care gratuitous benefits, then we are entitled to ask why he does not consistently exercise this power so that all beings might always be happy. That he does not do so would appear to indicate either God's insensitivity to our pain or his cruel willingness 
to see us undergo suffering that he could easily prevent. And so, the Buddhists conclude, whether God is unable to help us, unwilling to help us or unaware that we need help, he is of little value to man. We are better off conducting our affairs on our own powers and acting as if there is no divine power to help us in the task at hand, which is to transform our characters in such a way that we do only meritorious actions that naturally ripen into happy experiences in the present and future.

\subsection{THE PROBLEM OF UNITY IN GOD, INDIVIDUALS AND UNIVERSALS}

Of the issues concerning the existence of God that have been outlined above, the one that received the greatest attention from the Indian Buddhist academic tradition was that of the possibility of God's unity, simplicity and permanence. ${ }^{28}$ In fact, this principal argument for the nonexistence of God may be seen as a special application of a form of argument that occurs repeatedly in Buddhist metaphysical treatises, it being but another instance of the general Buddhist preoccupation with the problem of unity in diversity. Generally speaking, the Buddhist philosophers denied the existence of anything that was supposed to retain its unity while occurring in or being related to a plurality of things, as this verse from the Lañkāvatāra Sūtra acknowledges:

Personal identity, continuum, groups, causal conditions, atoms, primordial matter, and God the creator are regarded as mere ideas. ${ }^{29}$

Why each of these items is regarded as a purely conceptual fiction is that each is construed as a unity that is composed of a plurality of components. To give an exhaustive account of all occurrences of the Buddhist treatment of the one-many problem would be to tell nearly the whole story of Indian Buddhist philosophy, which is a bit like a symphony played on a one-stringed violin. Rather than attempting that monumental task here, let me simply outline four issues that at first glance might seem unrelated but which all turn out to be versions of the fundamental Buddhist claim that no whole exists over and above the existence of individual parts. Following this, I shall indicate briefly 
how this same fundamental claim was behind the Buddhist rejection of real universals and real relations.

\subsection{WHOLES AND PARTS}

Among the first Buddhist philosophical writings to become familiar to a relatively wide audience within the English-reading world was the celebrated Questions of King Milinda. In this text the monk Nāgasena is depicted as explaining to King Milinda that the personal identity that most people naively believe they possess is in fact no more than a mere designation, a convenient fiction. To demonstrate this principle, Nàgasena argues that the person is, like a chariot, really analyzable into discrete components, any one of which may be altered or replaced or deleted without impairing the supposed integrity of the collection of those parts. ${ }^{30}$ Just as a chariot's wheel can be replaced without altering the chariot's "identity" - that is, without making it a different chariot - a person's body can undergo changes, and some habits can be replaced by others, and knowledge can be gained or lost, and all these changes can occur without changing the person's "identity." But when we inquire into where this so-called identity resides, we find that it cannot reside in its totality in any one component part, nor can it reside in the set of parts taken as a whole. For if, let us say, the entire identity of the chariot were to reside in, for example, the left wheel, then the chassis and the axle and the right wheel would not be parts of the chariot at all, for the chariot would be just the left wheel. And if the left wheel should break and be replaced, we should have to say that the entire chariot was broken and replaced by an entirely different chariot. On the other hand, if we assume that the identity of the chariot resides in the collection of parts taken as a whole, then, since the whole changes any time any part changes, to replace any part would be to change the identity of the whole; to replace a single screw in the chariot would be to create a wholly different chariot. But it goes against our intuitions of the chariot's identity to say either that the chassis is not part of the chariot or that the change of a tiny part creates an entirely different chariot. This intuition of identity, then, is no more than an intuition. It resides 
purely in the mind of the beholder and has no counterpart in the world outside the mind. What we take to be a person is in fact devoid of personal identity. Further arguments along this line are developed in Vasubandhu (pp. 461-479) and throughout the Buddhist academic tradition.

In Uddyotakara's Nyāyavārttika under Nyāya-sūtra 2.1.31-33 there is a discussion concerning whether or not it is justifiable to infer, when one sees the part of a tree that one is facing, that the tree has a backside as well. Uddyotakara represents the Buddhists as being unable to regard such an inference as justifiable. In order to use an observation of $\mathrm{A}$ to serve as a sign of $\mathrm{B}$, say the Buddhists, one must have seen $A$ and $B$ together at some point and one must never have seen A without B. But it is impossible to see the face and back of a three-dimensional object simultaneously, and so one can never legitimately conclude that there is a backside to a tree or any other large object that one is facing. The Naiyayika is spared from having to hold such a patently silly view, thinks Uddyotakara, because he believes it possible to see not only the parts of the tree but the tree itself as a whole object. To see the front of a tree is to see a tree, and to see a tree is to know immediately that it must have a backside as well, since having sides facing all directions is part of what it is to be a tree. But the Buddhists, says Uddyotakara, continue to dispute this Naiyāyika claim by availing themselves of the following line of argument. We cannot say that the tree-as-a-whole resides entirely in any one part, such as a single leaf, for if that part were destroyed we should then have to say that the whole tree was destroyed. On the other hand, we cannot say that the tree-as-a-whole exists only partially in the single leaf, since that would entail admitting that the tree-as-a-whole is partite, which runs counter to our intuition that a whole is a unit rather than a mere assemblage of smaller units. And so, say the Buddhists, the tree-as-a-unit resides only in our mind and is not something that can be seen or in any way sensed as a datum of the world external to awareness.

In Pramāṇasamuccayavṛtti under kārikā 5.50, Dinnāga argues that proper names (yadrcchāśabda), usually regarded as words that apply only to given individuals, are in fact a type of class noun, since what we ordinarily think of as individuals are in fact complex objects. And 
so, just as the word "cow" applies to a plurality of objects that the intellect gathers together and treats as a unit called a class, a proper name like "Devadatta" applies to a plurality of traits that the intellect collects and treats as a unit called a person. But persons and classes are both convenient fictions for the supposed unity of which there is no justification in the facts of the world external to consciousness.

In the examples given so far, objects that are usually regarded naively as units have turned out on closer reflection to be complexes that because of their complexity in fact lack unity. Atoms, on the other hand, are defined as absolute simples in that they are divisions of matter than which nothing could be smaller. But the only unity than which nothing could be smaller must be without any dimension at all and so must not be a unit of matter at all, since unlike all other matter the atom cannot occupy space and be resistent to other units of matter occupying the same space. The same arguments are applied in some Buddhist works to the smallest possible unit of time, the moment (kșana).

Individuality, then, is merely an idea (cittamātra), say the Buddhist academics, for reason shows that things that are given in experience as existing, such phenomena as persons and chariots, have no real individuality, while things that theoretically have true individuality, such things as atoms and moments, cannot really exist.

\subsection{UNIVERSALS AND RELATIONS}

At Pramānasamuccaya 5.1-4, Dinnāga argues that the intellect's act of gathering a plurality of individuals together under a single concept is done without any basis in a real unity binding the objects together in the world external to consciousness. There are, in other words, no real universals that retain their unity while residing in a plurality of individuals. At Pramānasamuccaya 5.17 Dinnāga argues that if there were such a thing as a universal like cowness, then either it would have to reside in its entirety in a single individual cow or it would have to reside partially in each individual cow. In the former case there would then be only one cow, which is not what we in fact observe. In the latter case the universal cowhood would have internal divisions and so would not be a unity, which runs counter to the usual 
definition of a universal. Therefore universals do not reside in objects in any way at all, says Diñnāga; rather, they are superimposed by the mind upon the objects of experience.

Using an argument that is parallel to the argument against the existence of real universals, Dinnãga concludes that there are also no relations in the real world. For a relation is supposed to be a unity that binds a plurality of relata together. But if the relation is a real object in the world, then it must reside either wholly in a single relatum or partially in each, neither of which consequences is possible. Similarly, resemblance cannot be a real feature of objects in the world, for resemblance is a kind of relation. Resemblance, like any other relation and like universals, is something that the intellect superimposes upon the objects of experience rather than something that is a discovered feature of objects that they have outside our experience of them.

\subsection{CONCLUSION}

The doctrine that there is no permanent creator who superintends creation and takes care of his creatures accords quite well with each of the principles known as the four noble truths of Buddhism. The first truth, that distress is universal, is traditionally expounded in terms of the impermanence of all features of experience and in terms of the absence of genuine unity or personal identity in the multitude of physical and mental factors that constitute what we experience as a single person. As we saw above, the principal Buddhist arguments against the existence of God focus on the impossibility of permanence and unity in the causal structure of the universe. The second noble truth, that distress is the outcome of one's own unrealistic aspirations, is traditionally seen as ruling out the erroneous view that distress is something inflicted upon creatures by a cosmic superintendent or by other circumstances completely beyond their control. The third noble truth, that distress can be eliminated by divesting oneself of all unrealistic aspirations, rules out the view that sentient beings, as powerless victims of a divine will, have no alternative to a life of constant frustration. And the fourth noble truth, that the best means of removing unrealistic desires is to follow a methodical course of 
self-discipline, counters the view that the road to happiness lies in obedience to divine will or in trying to manipulate the sentiments of a cosmic intelligence through prayer or ritual.

Atheism, then, is a doctrine of fundamental importance within Buddhist religious philosophy rather than a mere accretion acquired through historical accident. As such it was a doctrine for which the Buddhist apologists during the academic period were strongly motivated to find good arguments. Although a variety of arguments were used, the most frequently used and the most powerful was a special application of the general Buddhist commitment to the principle that there can be no real unity binding together any plurality of things and that all notions of unity in plurality are therefore superimposed gratuitously upon experience by the experiencing mind. From this same principle the Buddhist scholastics in India also derived their commitment to nominalism or conceptualism in the realm of linguistic philosophy and to the theory of radical momentariness in the realm of metaphysics.

\section{NOTES}

1 Davids and Carpenter (1890), p. 18.

2 Davids and Carpenter (1890), p. 235.

3 Davids and Carpenter (1890), p. 240.

4 "Tayidam, bhikkave, Tathāgato pajānāti: 'Ime diț̣itțhānā evam-gahitā evamparāmatthā evam-gatikā bhavissanti evam-abhisamparäyã ti.'” Davids and Carpenter (1890), p. 30.

5 Chalmers (1898), pp. 214-228.

6 "samudayañānam issarapadhānakālasabhāvādīhi loko pavattatĩ ti akārane kāranābhimānapavattam hetumhi vippatịpattim." (Knowledge of the origin [of distress] puts an end to misconception with respect to causes, which concerns the belief that something is a cause when it is not, such as that the world arises owing to God, primordial matter, time or the inherent properties [of the material elements].)

Buddhaghosa, p. 1156.

? "tasmān na lokasyaikam kāraṇam asti. svāny evaișām karmāṇi tasyām tasyām jātau janayanti. akrtabuddhayas tu varākāh svam svam vipākaphalam cānubhavanta î́varam aparam mithyā parikalpayanti." Vasubandhu, p. 102, under Abhidharmakośa 2.64.

\& "evamin pradhāne'pi yathāyogam vācyam." Vasubandhu, p. 102.

9 "yadi hy ekam eva kāranam iśvarah syād anyad vā yugapat sarvena jagatā bhavitavyam syāt. dṛśyate ca bhāvānẳm kramasambhavah. sa tarhi cchandavaśād îsvarasya syād ayam idānīm utpadyatām nirudhyatām ayam pasćād iti. cchandabhedāt tarhi siddham anekam̉ kāranamàn syāt. sa cāpi cchandabhedo yugapat syāt taddhetor îśvarasyābhinnatvāt." Vasubandhu, pp. 101-102. 
10 yatra bhinne na tadbuddhir anyāpohe dhiyā ca tat/

ghatārthavat samivrtisat paramārthasad anyathā//AK 6.4//

Vasubandhu, p. 334.

11 "yaugapadye'pīśvaracchandānãm jagato na yaugapadyam. yathācchandam

utpādanād iti cet." Vasubandhu, p. 102.

12 "na. tesāmo paścād viśesābhāvāt." Vasubandhu, p. 102.

13 yathā tat kāraṇam vastu tathaiva tad akāranam/

yadā tat kāraṇam kena matam neștam akãranam//PV 1.23//

(That thing [which like God is permanent] is exactly the same way when it is not a cause as when it is a cause. When it is a cause, by what is it so recognized? Why is it not believed [to remain] a noncause?) Dharmakirti, p. 16.

14 svabhāvaparināmena hetur ańkurajanmani/

bhūmyādis tasya samiskāre tadviśeșasya darśanāt//PV 1.27//

(Soil and so forth, owing to a transformation of nature, is a cause of a seedling's arising, since the seedling's attributes [such as growth] are observed in the soil's constitution.) Dharmakirti, p. 17.

15 svabhāvabhedena vinā vyāpāro'pi na yujyate/ nityasyāvyatirekatvāt sāmarthyam ca duranvayam//PV 1.25//

(No activity is possible without a change in nature. Since a permanent thing is unchanging, its capacity to act is hard to believe.) Dharmakirti, p. 17.

16 sastrausadhäbhisambandhāc caitrasya vranarohane/

asambaddhasya kim sthānoh kāranatvam na kalpyate//PV 1.24//

(Owing to his contact with a weapon or with medicines, Caitra gets wounded or healed. But a permanent thing that is disassociated [from activity] is not considered to be a cause.) Dharmakirti, pp. 16-17.

17 yathā viśeșena vinā vișayendriyasamhatih/

buddher hetus tathedam cet ...//PV $1.28 / /$

(But could this [creation of the world by God] be similar to a sense-faculty's contacting a sense-object, which without changing [serves as] a cause of awareness?) Dharmakirti, p. 17.

18 Jayanta Bhatta (pp. 453 f.) reports a Buddhist argument for momentariness based on the principle that if a thing has an intrinsic, self-realizing potential, then that potential must be constantly actualized, for otherwise there is no accounting for how the potential becomes actualized just when it does and no sooner or later.

19 "kaś ca tāvad ísvarasyeyatā sargaprayāsenārthah. yadi prītis tām tarhi nāntareṇopāyam śaktah karttum iti na tasyām iśvarah syāt tathaiva cānyasmin." Vasubandhu, p. 102.

20 “yadi ceśvarah narakādiṣu prajām bahubhiś cetibhir upașștam sṛștvā tena prīyate namo'stu tasmai tādṛ́áyeśvarāya. sugitaś cāyam tam ārabhya śloko b̆havati.

yan nirdahati yat tỉkṣno yad ugro yat pratāpavān/ māmsaśonitamajjādo yat tato rudra ucyate//

Vasubandhu, p. 102.

21 "kim kimapi prayojanam anusaminhāya jagatsarge pravarttate prajāpatir evam eva vā. niṣprayojanāyām pravrttāv aprekṣāpūrvakāritvād unmattatulyo'sau bhavet." Jayanta Bhatta, p. 192. 
22 na ca krīdāpi nihśesajanatātańkakārinī/

āyāsabahulā ceyam kartum yuktā mahātmanah//

Jayanta Bhatta, p. 192.

23 "kāranāntarabhedāpekșane vā neśvara eva kāraṇam syāt. teșām api ca kramotpattau kāranāntarabhedāpeksanăd anavasthāprasan̉gah syăd ity anantarabhedāyāh kāranaparamịparāyā anāditvăbhyupagamād ayam iśvarakāranādhimuktah śākyapừrvìyam eva nyāyam nātivrttah syāt." (On the other hand, if God is dependent on a variety of other causal factors to create the world, then he is not in fact the cause of the world. And if other causal factors arise one after another, then there would be an infinite regress, since each would require a variety of anterior causes. And so he who believes that God is the creator does not really reject the Buddhist position, since he too believes that the sequence of causal conditions, in which one comes immediately after the other, is beginningless.) Vasubandhu, p. 102.

24 "ekam khalv api jagatah kāranam parigṛhnatānyeșām arthānām pratyaksah puruṣakāro nihnutah syāt. sahāpi ca kāranaih kārakam îśvaram kalpayatā kevalo bhaktibādah syāt. kẳraṇebhyo'nyasya tadutpattau vyāpārādarśanāt." Vasubandhu, p. 102.

25 sarvotpattimatām iśam anye hetum pracakșate/ nācetanam svakāryāni kila prārabhate svayam//TS 46// Sāntaraksita, p. 51.

${ }^{26}$ kintu nityaikasarvajñanityabuddhisamāśrayah / sādhyavaikalyato'vyāpter na siddhim upagacchati//TS 72// tathā hi saudhasopānagopurāttālakādayah/ anekānityavijñānapūrvakatvena niścitāh//TS 73// (But [the world's] dependence upon that which is eternal, one, and of unchanging, omniscient mind is a conclusion that does not admit of proof. Because [the property that the theist cites as evidence for that conclusion, namely, the fact that the world is a complex product] is not pervaded [by the property of depending upon that which is eternal, etc.], for the property that is in need of proof does not extend [to all created things]. For example, such things as houses, staircases, gateways and towers are known to be preceded by many beings with changing mental states.) Sāntaraksita, p. 63 .

27 buddhimatpūrvakatvam ca sāmānyena yad iṣyate/

tatra naiva vivādo no vaiśvarūpyam hi karmajam//TS $80 / /$

nityaikabuddhipūrvatvasādhane sādhyaśūnyatā/

vyabhicāraś ca saudhāder bahubhih karanekṣanāt//TS 81// Sāntarakșita, p. 65.

28 Another issue that came to be frequently discussed by the academics after Dinnāga's time was that of God as a revealer of truths to which mankind would without revelation have no access. As this issue has been treated in Hayes (1984), I have not discussed it any further in the present writing.

29 pudgalah samtatih skandhāh pratyayā anavas tathā' pradhānam îśvarah kartā cittamātram vikalpyate//

Vaidya, p. 34.

30 This discussion occurs in Sāstrĩ, pp. 19-20. 


\section{REFERENCES}

Buddhaghosa. Visuddhimagga. Edited with Dhammapāla's Paramatthamañjūsātịkā by Dr. Rewatadhamma. Vol. 2. Pāli Granthamālā, 3. Vārānasīi: Vārānaseyasamskrtaviśvavidyālaya, 1969.

Chalmers, Robert (1898). Editor. The Majjhima-Nikāya. Vol. 2. London: Pali Text Society, 1951 (reprint).

Davids, T. W. Rhys and J. Estlin Carpenter (1890). Editors. The Dïgha Nikāya. Vol. 1. London: Pali Text Society, 1967 (reprint).

Dharmakīrti. Pramānavārttikam. Edited with Manorathanandin's Vrtti by Svāmī Dvārikādāsa Sāstrī. Bauddha Bharati, 3. Vārānasī: Bauddhabhāratī, 1968.

Dinnāga. The Pramānasamuccayavrtti of Dignāga. Chapter Five: Anyāpoha-parīksā. Tibetan text edited with Jinendrabuddhi's commentary by Masaaki Hattori. Memoirs of the Faculty of Letters, 21. Kyōto: Kyoto University, 1982.

Hayes, Richard P. (1984). "The question of doctrinalism in the Buddhist epistemologists." Journal of the American Academy of Religion 52: 645-670.

Jayanta Bhatta. The Nyāyamañjari. Edited by Gañgādhara Sāstrī Tailanga. Vizianagram Sanskrit Series, 10. Benares: E. J. Lazarus \& Co., 1895.

Sāntarakṣita. Tattvasangrahah. Edited with Kamalasinla's Pañjikā by Svāmī Dvārikādāsa Sāstrî. Vol. 1. Bauddha Bharati, 1. Vārānasĩ: Bauddhabhāratī, 1968.

Sāstrī, Svāmī Dvārikādāsa (1979). Editor. Milindapañhapāli. Bauddha Bharati, 13. Vārānasī: Bauddhabhāratī.

Uddyotakara. Nyāyavārttika. Edited by V. P. Dvivedin and L. S. Dravid. Kashi Sanskrit Series, 33. Vārānasī: Kashi Sanskrit Series, 1916.

Vaidya, P. L. (1963). Editor. Saddharmalankkāvatārasūtram. Buddhist Sanskrit Texts, 3. Darbhanga: Mithilâvidyāpitha.

Vasubandhu. Abhidharmakośabhāṣyam. Edited by P. Pradhan, 1967. Revised second edition by Aruna Haldar. Tibetan Sanskrit Works Series, 8. Patna: K. P. Jayaswal Research Institute, 1975 (2nd ed.). 